\title{
ONDE FRAGMENTOS DA ÁFRICA SE CRUZAM: O TRÁFICO DE AFRICANOS E O PORTO DE SALVADOR NO SÉCULO XVIII
}

\author{
WHERE FRAGMENTS OF AFRICA INTERSECT: THE TRAFFIC OF \\ AFRICANS AND THE PORT OF SALVADOR IN THE XVIII CENTURY
}

\author{
Daniele Santos de Souza \\ Instituto Federal de Educação, Ciência e Tecnologia da Bahia \\ Orcid: 0000-0002-9236-4826
}

\begin{abstract}
Resumo: Salvador foi o segundo maior porto das Américas em volume de escravizados desembarcados durante o tráfico transatlântico de africanos. Este artigo pretende analisar como este porto se organizava de modo a estruturar o comércio negreiro, atendendo a logística das armações, a construção e a manutenção dos navios, bem como a oferta de mão de obra especializada para as tripulações formadas, sobretudo, por africanos escravizados e libertos.
\end{abstract}

Palavras-chave: porto de Salvador; tráfico de escravos; escravidão.

Abstract: Salvador was the second largest port in the Americas in terms of the volume of enslaved disembarkation during the transatlantic slave trade Africans. This article intends to analyze how this port was organized in order to structure the slave trade, complying with the logistics, construction and maintenance of vessels, as well as the offer of specialized labor for the crews formed, above all, by enslaved and freed Africans.

Key-words: Salvador port, slave trade, slavery. 


\section{Introdução:}

A Cidade da Bahia, como era mais conhecida Salvador, foi marcadamente um espaço africano ao longo dos Setecentos. O tráfico negreiro foi sem dúvida o principal responsável por esse fato, devido aos números crescentes de desembarques no decorrer dessa centúria. Por outro lado, o comércio de cativos demandava mão de obra especializada e infraestrutura. Ironicamente, isto também contribuiu para acentuar a africanidade da Cidade da Bahia. Ou seja, parte dos escravizados que aportavam na Baía de Todos-os-Santos permaneceu em Salvador e foi empregada na logística do mesmo comércio que os havia transportado para este lado do Atlântico. Há algumas décadas, a historiografia vem destacando a intensa utilização de mão de obra africana, tanto escrava quanto liberta, a bordo dos navios, onde labutavam como marinheiros, grumetes, serventes, tanoeiros, calafates, barbeiros, além de atuarem como línguas, isto é tradutores nos portos africanos. Esta presença não se dava apenas nos negreiros, devido à escassez de braços brancos, principalmente nos espaços coloniais, se estendia para outras carreiras mercantes.

Os trabalhos de Peter Linebaugh e Marcus Rediker deram os primeiros passos nos estudos sobre pirataria, marinhagem e tráfico negreiro no Atlântico Norte entre os séculos XVII e XVIII. Estas pesquisas introduziram os métodos da história social para compreensão das relações a bordo dos navios negreiros, mercantes e piratas na época moderna até o período revolucionário entre fins dos Setecentos e início do Oitocentos. No Brasil, historiadores como Jaime Rodrigues e Luiz Geraldo Silva mergulharam seus estudos sobre as gentes do mar, principalmente entre aqueles envolvidos no tráfico transatlântico de escravizados. Por outro lado, trabalhos como o de João José Reis, Flávio Gomes e Marcus Carvalho ressaltaram a participação e o protagonismo de africanos a bordo dos navios negreiros, atuando inclusive como pequenos comerciantes, agentes e intermediários do tráfico. $^{1}$

\footnotetext{
${ }^{1}$ Peter Linebaugh e Marcus Rediker, A hidra de muitas cabeças: marinheiros, escravos, plebeus e a história oculta do Atlântico revolucionário (São Paulo: Companhia das Letras, 2008). Marcus Rediker, O navio negreiro: uma história humana (São Paulo: Companhia das Letras, 2011). Marcus Rediker, Villains of all Nations. Atlantic Pirates in the Golde Age (Boston: Beacon Press, 2004) Jaime Rodrigues, De costa a costa: escravos, marinheiros e intermediários do tráfico negreiro de Angola para o Rio de Janeiro (1780-1860) (São Paulo: Companhia das Letras, 2005). Luiz Geraldo Silva, A faina, a festa e o rito: uma etnografia histórica sobre as gentes do mar (sécs. XVII ao XIX) (Campinas: Papirus, 2001). João José Reis, Flávio dos Santos
} 
Este artigo percorre o caminho aberto por estes estudos e pela historiografia da escravidão atlântica nas últimas três décadas para discutir o emprego de africanos e seus descendentes no negócio que, entre os séculos XVI e XIX, transportou quase 13 milhões de indivíduos da África para as Américas. ${ }^{2}$ Deste modo, pretende-se analisar como o porto de Salvador organizava-se visando estruturar o comércio negreiro. Assim, o texto embarca nos navios negreiros para entender o trabalho a bordo e desembarca deles para compreender a logística das armações, a construção e a manutenção dos navios, bem como a oferta de mão de obra especializada para as tripulações. Neste ínterim, foi um importante ponto de partida o trabalho pioneiro de Amaral Lapa sobre a Bahia e a carreira da Índia, em especial, sobre a introdução da indústria naval no porto de Salvador para construção e reparo de embarcações. Destaco também a pesquisa de Mary Hicks sobre marinheiros africanos e crioulos em Salvador e suas redes de circulação de mercadorias entre a Bahia e a costa africana no período setecentista. ${ }^{3}$

O grosso da mão de obra da construção naval, tanto na Ribeira das Naus quanto nos demais estaleiros da cidade, era formada por libertos, escravos, alguns destes pertencentes à Sua Majestade, bem como presos das galés - entre os quais também havia cativos. Por isso, nos espaços em que se fabricavam as embarcações também se forjavam identidades e laços de solidariedade, assim como conflitos e disputas. Como a Costa da Mina foi a região africana privilegiada para o tráfico baiano, é sobre esta rota que a maior parte da documentação e, por tabela, das análises deste artigo se direcionam. Este artigo, portanto, visa contribuir para compreensão do tráfico negreiro a partir dos agentes que laboravam a bordo dos navios, bem como na sua construção e manutenção, tendo em vista ter sido Salvador o principal portos negreiro do Brasil colonial até fins do século XVIII.

\section{Uma cidade marítima e africana}

Gomes e Marcus J M de Carvalho, O Alufá Rufino: tráfico, escravidão e liberdade no Atlântico negro (c.1822c.1853) (São Paulo: Companhia das Letras, 2010).

2 Conforme dados do Tran-Atlantic Slave Trade Database (doravante TSTD), https://www.slavevoyages.org/voyage/database\#tables, acessado em 05/04/2021.

${ }^{3}$ José Roberto do Amaral Lapa, A Bahia e a Carreira da Índia (Ed. Fac-similar, São Paulo: Hucitec, Unicamp, 2000). Mary Ellen Hicks, "The Sea and the Shackle: African and Creole Mariners and the Making of a LusoAfrican Atlantic Commercial Culture, 1721-1835" (Tese de Doutorado, University of Virginia, 2015). 
A Cidade da Bahia, ao longo de todo o século XVIII, ostentou um alto percentual de africanos em meio à sua população escrava. Através da pesquisa nos inventários postmortem de senhores residentes em Salvador nos Setecentos, disponíveis no Arquivo Público Bahia, foi elaborado um banco de dados descrevendo a propriedade cativa arrolada nesta série documental. Nesta base de informações inseriu-se nome, origem, idade descritiva, ocupação, estado de saúde sobre os escravizados, além de dados eventuais como: menções a fugas, alforria, óbitos, relações conjugais, bem como ocupação e padrão de posse senhorial. Este banco de dados foi utilizado como suporte para outras pesquisas e neste artigo visa contribuir para compreensão acerca da paisagem escravista na Cidade da Bahia. ${ }^{4}$ Ao todo foram analisados 261 inventários, reunindo dados sobre 2.294 cativos, dos quais temos a informação sobre a origem de 2.180, sendo que lavradores e senhores de engenhos do Recôncavo que tiveram seus bens inventariados em Salvador não foram inseridos nesse cômputo, uma vez que suas atividades não eram predominantemente urbanas.

Levando em consideração a amostra presente nos inventários, durante o século XVIII, aproximadamente $63 \%$ dos cativos eram africanos. Ou seja, Salvador permaneceu dispondo de uma população escrava majoritariamente africana. Isto ocorreu a despeito da grande demanda por escravos na região de Minas Gerais, na primeira metade do Setecentos, ou do franco processo de crioulização demográfica em curso no Recôncavo baiano, na segunda metade dessa centúria. ${ }^{5}$ Embora houvesse uma predominância de pessoas oriundas da Costa da Mina - os dados dos inventários demonstram que 36,2\% dos escravizados vinham dessa região -, a pluralidade de origens africanas era significativa. Não raro, termos genéricos, como "gentio da costa" e "angola", cediam espaço para denominações étnicas mais

\footnotetext{
${ }^{4}$ Daniele Santos de Souza, "Entre o "serviço da casa" e o "ganho": escravidão em Salvador na primeira metade do século XVIII", (Dissertação de Mestrado, Departamento de História, Universidade Federal da Bahia, 2010); Daniele Santos de Souza, "Tráfico, escravidão e liberdade na Bahia nos "anos de ouro" do comércio negreiro (c.1680-c.1790)" (Tese de Doutorado, Departamento de História, Universidade Federal da Bahia, 2018).

${ }^{5}$ Ao longo da pesquisa, vários inventários post-mortem tiveram a sua consulta suspensa pelo Arquivo Público do Estado da Bahia, devido às precárias condições de conservação de alguns destes documentos. De modo que a complementação das informações deste banco de dados somente foi possível graças ao professor Nicolau Parés, o qual agradeço por ter me concedido acesso ao seu levantamento acerca dos inventários post-mortem da segunda metade do século XVIII. Arquivo Público do Estado da Bahia (doravante APEB), Seção Judiciária, Inventários post-mortem 1700-1800. Luis Nicolau Parés, "O processo de crioulização no Recôncavo baiano (1750-1800)", Afro-Ásia, Salvador, v. 33, 2005, pp. 70-101. Durante os anos de 1700-1750, a taxa de africanidade alcançou $68 \%$ dos escravos listados nos inventários, enquanto para a segunda metade teve uma leve queda, chegando a $61,4 \%$.
} 
complexas, como "codavi” e "ganguela", construídas no processo diaspórico. ${ }^{6}$ Aqueles nascidos no Brasil perfaziam 37,4\%, com destaque para os crioulos que alcançavam $24,7 \%$. Em geral, os cativos nascidos na colônia, principalmente os mestiços, eram preferidos pelos senhores para serem engajados, ainda pequenos, no aprendizado de ofícios especializados, de acordo com os interesses de seu dono. Nos espaços urbanos, alguns cativos aprendiam o ofício que o seu senhor por ventura fosse mestre ou tivesse ligação com o seu ramo de negócios. $\mathrm{O}$ ensino dessas atividades poderia ser realizado tanto por brancos quanto por negros escravizados e libertos, fossem eles nascidos no Brasil ou africanos ladinos. Por conhecerem a língua portuguesa, estarem socializados ao mundo da escravidão desde a infância e desfrutarem da estima e confiança senhorial, crioulos e mestiços eram maioria entre os escravos que dominavam ofícios especializados. ${ }^{7}$

No que tange aos ofícios do mar, contudo, a regra era outra. Nessas atividades havia um predomínio de africanos, como vem apontando, há algum tempo, Jaime Rodrigues e Luiz Geraldo Silva. A aprendizagem da lide marítima estava ligada, sobretudo, à experiência em alto mar, um trabalho árduo e de grande risco, talvez, justamente por isso, se empregassem mais africanos, costumeiramente relegados às atividades mais duras e perigosas. ${ }^{8}$

Nos inventários analisados, somente foi possível identificar a ocupação de 1.212 cativos, distribuídos nas mais variadas atividades nas ruas, praças, ladeiras, sobrados e roças das freguesias da cidade. O labor doméstico prevalecia entre os escravos urbanos, cerca de $36,4 \%$ foram descritos como do "serviço da casa" ou em atividades correlatas como cozinheira ou lavadeira. No entanto, a exploração sobre sua força de trabalho se estendia desde o pequeno comércio (3,7\% da amostra), passando pelos serviços de transporte de

\footnotetext{
${ }^{6}$ Sobre as nações africanas na Bahia setecentista ver: Luis Nicolau Pares, A Formação do Candomblé: história e ritual da nação jeje na Bahia ( ${ }^{\mathrm{a}}$ ed. rev., Campinas: Ed. Unicamp, 2007), pp. 63-100. Carlos Francisco da Silva Jr. "Identidades Afro-Atlânticas: Salvador, Século XVIII (1700-1750)", (Dissertação de Mestrado, Departamento de História, Universidade Federal da Bahia, 2011), pp. 90-115.

${ }^{7}$ Maria Helena Ochi Flexor, "Os ofícios mecânicos e o negro no espaço urbano de Salvador", Atas do IV Congresso Internacional do Barroco Íbero-Americano, pp. 811-833. Daniele Santos de Souza, "Entre o "serviço da casa" e o "ganho": escravidão em Salvador na primeira metade do século XVIII", (Dissertação de Mestrado, Departamento de História, Universidade Federal da Bahia, 2010) pp. 60-101.

${ }^{8}$ Jaime Rodrigues, De costa a costa: escravos, marinheiros e intermediários do tráfico negreiro de Angola para o Rio de Janeiro (1780-1860) (São Paulo: Companhia das Letras, 2005), pp. 159-184. Luiz Geraldo Silva, A faina, a festa e o rito, pp. 155-197.
} 
pessoas e mercadorias $(8 \%)$, pela pesca $(7,2 \%)$, pelo trabalho nas roças dos subúrbios da cidade $(17,2 \%)$ e por uma enorme gama de ofícios especializados $(27,5 \%){ }^{9}$

A faina diária poderia ser prestada diretamente ao senhor, a um terceiro para o qual o cativo fora alugado ou por meio do sistema de ganho, quando o escravo oferecia seus préstimos nas ruas da cidade. Neste último caso, era previamente acertado com o senhor um valor diário ou semanal a ser pago. Se por um lado, este sistema assegurava certa autonomia ao cativo, por outro tornava mais eficaz a exploração e mais efetivo o lucro senhorial. No ganho, o escravo realizava desde o transporte de mercadorias (sozinho ou em grupo) ou de pessoas em cadeiras de arruar, passando por ofícios especializados como sapateiro, pedreiro, carpinteiro, barbeiro até a comercialização de alimentos in natura e/ou preparados. ${ }^{10}$

Parte significativa dos cativos da Cidade e do Recôncavo da Bahia estava empregada na navegação, fosse ela de longo curso, de cabotagem entre as capitanias do Brasil ou dentro das Baías de Todos-os-Santos e de Camamu e nos rios que nelas deságuam. Ademais, poderiam ser alugados a investidores das carregações do comércio de longo curso ou aos proprietários das embarcações que cruzavam o Atlântico. O tanoeiro Simão Angola, pertencente ao casal Eufrásia de Jesus e Francisco Jorge, por exemplo, foi alugado junto com outros cativos de seus senhores, também tanoeiros, ao capitão Manoel de Oliveira Rocha, para seguirem viagem à Costa da Mina na galera $N^{a} S^{a}$ do Monte do Carmo e Senhor do Bonfim. ${ }^{11}$ Em outros casos, os escravos podiam trabalhar em navios pertencentes a seus senhores ou capitaneados por eles, como os marinheiros José e Simão ambos do gentio da costa e João angola e Felipe moçambique, que embarcavam junto com o seu senhor, o capitão de navio negreiro João Batista Pires. Da mesma forma, os escravos marinheiros João e Antônio seguiram abordo junto com seus senhores - o capitão Antônio da Costa Bastos e

\footnotetext{
${ }^{9}$ APEB, Seção Judiciária, Inventários post-mortem, 1700-1800.

${ }^{10}$ Sobre o sistema de ganho na Bahia setecentista ver: Daniele Souza, "Entre o serviço da casa e o ganho", pp. 60-94. Para a Bahia no século XIX cf. João José Reis, Ganhadores. A greve negra de 1857 na Bahia (São Paulo: Companhia das Letras, 2019), pp. 35-67. João José Reis, Rebelião Escrava no Brasil. A História do Levante dos Malês em 1835. (Edição Revista e Ampliada, São Paulo: Companhia das Letras, 2003), pp. 350389.

${ }^{11}$ APEB, Seção Judiciária, Inventário post-mortem de Eufrasia do Nascimento de Jesus, 1752, classificação: 04/1572/2041/06. TSTD viagem \#50738.
} 
o escrivão Jacinto José Coelho, respectivamente - em direção à Costa da Mina, na corveta $N^{a} S^{a}$ da Esperança e São José. ${ }^{12}$

Entre os escravos arrolados nos inventários como dotados de ofícios especializados, cerca de 15,5\% desenvolviam atividades relacionadas ao trabalho a bordo das embarcações, atuando como tanoeiros, marinheiros, calafates, mestre de lancha e até mesmo arrais. ${ }^{13} \mathrm{Se}$ somarmos com aqueles que exerciam atividades de pesca, ao todo cerca 11,5\% dos cativos listados nos inventários possuíam o mar como seu principal espaço de trabalho. Nesse cômputo, contudo, não foram inseridos outros ofícios cruciais para a navegação e manutenção das embarcações, como o de carpinteiro, serralheiro, tanoeiro, calafate e barbeiro. Oficiais barbeiros e sangradores eram comumente utilizados nos navios negreiros para tratarem tanto dos enfermos da tripulação, quanto do contingente escravo que seguia a bordo. $^{14}$

Entre os cativos pertencentes ao capitão negreiro Manoel Ferreira de Oliveira, por exemplo, havia o marinheiro Antônio do gentio da costa e o molecão, barbeiro e sangrador Ignácio, da mesma origem. ${ }^{15}$ José Vieira de Brito, também capitão de navio negreiro, contava com o crioulo Ventura, que dominava os ofícios de barbeiro, sangrador e marinheiro, para auxiliá-lo nas viagens à Costa da Mina. ${ }^{16} \mathrm{Na}$ viagem armada pelo traficante José de Souza Reis, proprietário da corveta $N^{a} S^{a}$ da Esperança e São José, em direção à Costa da

12 APEB, Seção Judiciária, Inventário post-mortem de João Batista Pires, 1783, classificação: 05/2166/2635/08. Pires capitaneou pelo menos quatro viagens para a costa da Mina, entre os anos de $1772 \mathrm{e}$ 1779, cf. TSTD viagens: \#49647, \#50977, \#50999, \#51028. Arquivo Histórico Ultramarino (doravante AHU), Conselho Ultramarino (doravante CU), 005-01 Coleção Eduardo Castro e Almeida, Requerimento do negociante José de Souza Reis à rainha, solicitando para ser indenizado por prejuízos sofridos com a perda da sua corveta Nossa Senhora da Esperança e São José, que os holandeses tinham apresado, em 1767, quando tinha sido fretada pelo governador da Bahia, conde de Azambuja, para conduzir à Ilha do Príncipe, o governador e capitão general de São Tomé e Príncipe, Lourenço Lobo de Almeida, próximo a Costa da Mina, onde tinham sido largados o capitão António da Costa Bastos e a tripulação, 1777, Cx. 51, D. 9619-9631.

${ }^{13}$ Arrais é o mestre de embarcações de pequeno porte, é a pessoa que conduz o barco. Segundo Bluteau, é o patrão de galé. Padre d. Raphael Bluteau, Vocabulário portuguez e latino (Coimbra, Colégio das Artes da Companhia de Jesus, 1712), verbete "arrais".

${ }^{14}$ Rodrigues, De Costa a Costa, pp. 252-296. Mariza de Carvalho Soares, "African Barbeiros in Brazilian Slave Ports", in: Cañizares-Esguerra, Jorge; Childs, Matt D.; Sidbury, James (orgs.) The Black Urban Atlantic in the Age of the Slave Trade (University of Pennsylvania Press, Philadelphia, Ebook, 2013), pp. 207-230.

${ }^{15}$ APEB, Seção Judiciária, Inventário post-mortem de Manoel Ferreira de Oliveira, 1762, classificação: 04/1613/2082/05.

16 APEB, Seção Judiciária, Inventário post-mortem de José Vieira de Brito, 1768, classificação: 03/971/1440/09. TSTD viagens: \#50888 e \#50908. 
Mina, em 1767, seguiram a bordo nove escravos ladinos pertencentes ao senhorio da embarcação. Os tripulantes eram os barbeiros Joaquim e Ignácio, ambos jejes, e os marinheiros Matheus, Thomas, Felipe, Joaquim e Domingos, também jejes, e os marítimos Manoel e Christovão, angolas. A corveta havia sido fretada pelo governador-geral da Bahia, conde de Azambuja, para conduzir o recém-nomeado governador e capitão general das ilhas de São Tomé e Príncipe, Lourenço Lobo de Almeida. Contudo, pouco depois do desembarque deste governador, ao chegar ao Cabo Lahu, na Costa da Mina, antes mesmo de iniciar as primeiras operações, a corveta foi apresada pelos holandeses. Estes, diante de uma escravaria qualificada e experiente nas lides do mar, não se acanharam e confiscaram os tripulantes cativos junto com a carga. ${ }^{17}$

\section{TABELA 1}

OCUPAÇÕES MARÍTIMAS NOS INVENTÁRIOS (1700-1800)

\begin{tabular}{|c|c|c|c|c|c|c|c|c|}
\hline Origem/cor & $\begin{array}{l}\text { Mari } \\
\text { nheir } \\
\text { o }\end{array}$ & $\begin{array}{l}\text { Calaf } \\
\text { ate }\end{array}$ & $\begin{array}{l}\text { Tan } \\
\text { oeiro }\end{array}$ & $\begin{array}{l}\text { Arra } \\
\text { is de } \\
\text { emb } \\
\text { arca } \\
\text { ção }\end{array}$ & $\begin{array}{l}\text { Mest } \\
\text { re de } \\
\text { lanc } \\
\text { ha }\end{array}$ & $\begin{array}{l}\text { Serv } \\
\text { iço } \\
\text { do } \\
\text { mar }\end{array}$ & $\begin{array}{l}\text { Barque } \\
\text { iro }\end{array}$ & $\begin{array}{l}\text { Total } \\
\%\end{array}$ \\
\hline Mina & 14 & 5 & 2 & & & & & $\begin{array}{l}21 \\
(41,2 \%)\end{array}$ \\
\hline São Tomé & & & & & & 1 & & $1(2,0 \%)$ \\
\hline Angola & 8 & & 3 & & & & & $\begin{array}{l}11 \\
(21,5 \%)\end{array}$ \\
\hline Benguela & 2 & & & & & & & $2(3,9 \%)$ \\
\hline Moçambique & 3 & & & & & & & $3(5,9 \%)$ \\
\hline Desconhecido $^{18}$ & 3 & & & & & & 1 & $4(7,8 \%)$ \\
\hline
\end{tabular}

\footnotetext{
${ }^{17}$ AHU, CU, Coleção Castro e Almeida, Requerimento do negociante José de Souza Reis à rainha, solicitando para ser indenizado por prejuízos sofridos com a perda da sua corveta Nossa Senhora da Esperança e São José, que os holandeses tinham apresado, em 1767, quando tinha sido fretada pelo governador da Bahia, conde de Azambuja, para conduzir à Ilha do Príncipe, o governador e capitão general de São Tomé e Príncipe, Lourenço Lobo de Almeida, próximo a Costa da Mina, onde tinham sido largados o capitão António da Costa Bastos e a tripulação. 1777, Cx. 51, D. 9619-9631.

${ }^{18}$ Um cativo designado como "Guiné" e dois cuja origem não foi informada.
} 


\begin{tabular}{|c|c|c|c|c|c|c|c|c|}
\hline Crioulo & $\mid 1$ & 1 & & 2 & 2 & & & $6(11,8 \%)$ \\
\hline Mestiço $^{19}$ & 3 & & & & & & & $3(5,9 \%)$ \\
\hline $\begin{array}{l}\text { Total } \\
\%\end{array}$ & $\begin{array}{l}34 \\
(66,7 \%)\end{array}$ & $\begin{array}{l}6 \\
(11,7 \% \\
)\end{array}$ & $\begin{array}{l}5 \\
(9,8 \% \\
)\end{array}$ & $\begin{array}{l}2 \\
(3,9 \% \\
)\end{array}$ & $\begin{array}{l}2 \\
(3,9 \% \\
)\end{array}$ & $\begin{array}{l}1 \\
(2,0 \% \\
)\end{array}$ & $\begin{array}{l}1 \\
(2,0 \%)\end{array}$ & $51(100 \%)$ \\
\hline
\end{tabular}

Fonte: APEB, Seção Judiciária, Inventários post-mortem, 1700-1800.

Proprietários de embarcações e capitães de navios negreiros, em geral, dispunham de cativos que dominavam os ofícios ligados ao trabalho marítimo e costumavam utilizá-los durante suas viagens. Os cinco tanoeiros apresentados na tabela acima, por exemplo, foram arrolados no inventário de Eufrásia do Nascimento de Jesus, cujo casal possuía uma embarcação empregada na navegação de cabotagem entre a Baía de Todos-os-Santos e a capitania de Sergipe Del Rei. Além disso, investiam em carregações que seguiam para a Costa da Mina, para as quais também alugavam seus escravos tanoeiros. ${ }^{20}$ Dos cinco inventários localizados pertencentes a capitães negreiros, quatro possuíam cativos marinheiros, nos quais constavam nove dos 34 marinheiros identificados nesta série documental. ${ }^{21}$ No entanto, nem todos os marinheiros listados nos inventários assumiam as lides da travessia atlântica em direção à Costa da África, mesmo aqueles pertencentes a capitães e senhorios de navios. A maioria era empregada na navegação de cabotagem e no transporte de açúcar, fumo, farinha e outros produtos da terra entre as águas da Baía de Todos-os-Santos e os rios que nela desaguavam. Por isso, encontramos dois cativos descritos como mestre de lancha e dois como arrais de embarcação e dos 34 marítimos, pelo menos sete foram listados como marinheiros de lancha.

\footnotetext{
${ }^{19}$ São eles: um pardo, um mestiço, um mulato.

${ }^{20}$ APEB, Seção Judiciária, Inventário post-mortem de Eufrasia do Nascimento de Jesus, 1752, classificação: 04/1572/2041/06.

${ }^{21}$ Os inventários identificados no APEB como pertencentes a capitães negreiros foram os seguintes: Inventário post-mortem de Jacinto Gomes, 1752, classificação: 03/1147/1616/02; Inventário post-mortem de João Batista Pires, 1783, classificação: 05/2166/2635/08; Inventário post-mortem de José Pereira Cruz, 1750, classificação: 7-3195-0-9; Inventário post-mortem de José Vieira de Brito,1768, classificação: 03/971/1440/09; Inventário post-mortem de Manoel Ferreira de Oliveira, 1762, classificação: 04/1613/2082/05; APEB, Seção Judiciária. Sobre os capitães de navios negreiros, ver: Cândido Eugênio Domingues de Souza,"“Perseguidores da espécie humana': capitães negreiros da Cidade da Bahia na primeira metade do século XVIII”, (Dissertação de Mestrado, Departamento de História, Universidade Federal da Bahia, 2011).
} 
A proporção de africanos oriundos da Costa da Mina em meio àqueles que trabalhavam em alto mar era levemente superior à sua representação junto a população cativa da cidade, $41,2 \%$ frente a $36,1 \%$, respectivamente. Ou seja, esses cativos tinham papel de destaque não apenas no transporte marítimo na capitania, mas também no próprio tráfico negreiro, fechando um ciclo que retroalimentava a escravidão africana. Embarcados, esses marinheiros africanos atuavam também como tradutores nos portos da Costa da Mina, facilitando a negociação entre o capitão e os negociantes locais. O papel de língua se estendia para bordo da embarcação e era fundamental para a comunicação e vigilância sobre aqueles que seguiam no porão do navio durante o retorno da viagem. Segundo Nadine Hunt, Olaudah Equiano durante sua experiencia na escravidão, numa viagem da Jamaica para a América Central no contexto do tráfico de escravos intra-caribenho, relata como teria auxiliado na escolha de cativos para trabalharem nas plantações, utilizando a língua africana para selecionar escravizados de origem semelhante à sua. ${ }^{22}$

A especialização no trabalho marítimo e a possibilidade de ascensão a postos superiores na hierarquia também acompanharam a lógica da própria escravidão, ou seja, as chances eram maiores para aqueles nascidos no Brasil. Os postos de mestre e arrais de embarcações de pequeno porte, como barcos, lanchas e saveiros, eram ocupados, principalmente, por marinheiros brancos, segundo o mapa sobre a navegação na capitania da Bahia encaminhado à Coroa pelo governador Manuel da Cunha Menezes, em 1775. Por isso, nos inventários, há um percentual mínimo, provavelmente excepcional, de quatro cativos ocupando esses postos, todos crioulos, conforme a tabela 1. Mestres e arrais tinham a responsabilidade de transportar os "gêneros e víveres que fomentam o comércio e sustenta a cidade", ou seja, a produção de açúcar e fumo que seguia para Europa, África e Ásia, bem como outros gêneros alimentícios e os bens importados pela capitania, tarefa que exigia habilidade e perspicácia do condutor. ${ }^{23}$ Por isso, semelhante ao que alguns senhores faziam

\footnotetext{
${ }^{22}$ Nadine Hunt, "Scattered Memories: The Intra-Caribbean Slave Trade to Spanish America, 1700-1750", in: Ana Lucia Araujo, Mariana P. Candido and Paul E. Lovejoy, Crossing Memories: Slavery and African Diaspora, New Jersey: Africa World Press, 2011, pp. 105-127. Ver também: Jaime Rodrigues, De Costa a Costa, pp. 198-199.

${ }^{23}$ AHU, CU, 005-01 Bahia - Coleção Eduardo Castro e Almeida, Mapa dos tipos de embarcações que havia na capitania da Bahia, e que navegavam para a Costa da Mina, Angola, e outros portos da África, Rio de Janeiro, Pernambuco, Pará, e outros portos do Brasil, dos barcos, lanchas e pequenas embarcações que navegavam pelos rios e ribeiras dessa capitania, conduzindo viveiros e pescados para sua manutenção, com o
} 
em relação à ocupações especializadas, não é de se estranhar que negociantes, lavradores e senhores de engenho, quando possível, creditassem ser interessante delegar a função de arrais e mestre aos seus cativos de confiança nascidos no Brasil.

O mesmo mapa que aponta o engajamento de brancos como mestres e arrais de pequenas embarcações, também destaca a presença de libertos nas lides do mar, alguns, talvez, exercessem esta ocupação desde os tempos de cativeiro. Esse documento foi remetido, em 27 de maio de 1775, pelo governador Manuel da Cunha Menezes ao secretário de Estado da Marinha e Ultramar Martinho de Melo e Castro. O objetivo do governador era responder ao questionamento régio, feito no ano anterior, sobre o estado da navegação e da pesca da baleia na capitania. O mapa encaminhado a Lisboa descrevia os tipos de embarcação que navegavam entre a Baía de Todos-os-Santos, o reino e os portos da costa brasileira e africana, bem como os "barcos, lanchas, e outras pequenas embarcações que navegam pelos rios, ribeiras" da capitania no transporte de mercadorias e na pesca. O documento também apresentava o número de marinheiros e pescadores forros e cativos existentes na capitania, informando em quais freguesias residiam. ${ }^{24}$

De acordo com as contas apresentadas por Manuel da Cunha Menezes, a maioria dos marinheiros da Cidade da Bahia vivia nas freguesias portuárias de $\mathrm{N}^{\mathrm{a}} \mathrm{S}^{\mathrm{a}}$ da Conceição da Praia e Santíssimo Sacramento do Pilar. E não poderia ser diferente, pois nelas se encontrava o centro comercial da cidade com as principais lojas de varejo, os armazéns, os trapiches e os mercados onde se vendiam os africanos recém desembarcados. Além disso, depois da Sé, essas eram as duas freguesias mais populosas da cidade, conforme um censo realizado no

número de marinheiros, pescadores forros e cativos que haviam na capitania, e freguesias onde moravam, 27/05/1775, Cx. 47, D. 8790 e 8812. Há duas versões deste documento na Coleção Eduardo Castro e Almeida. Na primeira, sob o número de 8790 , não consta a quantidade de marinheiros e pescadores na freguesia do Santíssimo Sacramento da Rua do Passo. O registro destes dados consta no documento 8812, por isso há uma diferença na soma total de marinheiros forros e cativos. No primeiro documento eles são 671 e 1202, respectivamente, e no segundo totalizam 678 e 1227. Este mapa também foi citado por Carlos Francisco Silva Jr. "Identidades atlânticas" pp. 86-87, além de ter sido analisado por Mary Ellen Hicks, "The Sea and the Shackle: African and Creole Mariners and the Making of a Luso-African Atlantic Commercial Culture, 17211835" (Tese de Doutorado, University of Virginia, 2015), pp. 118-119.

${ }^{24}$ AHU, CU, 005-01 Bahia - Coleção Eduardo Castro e Almeida, Mapa dos tipos de embarcações que havia na capitania da Bahia, e que navegavam para a Costa da Mina, Angola, e outros portos da África, Rio de Janeiro, Pernambuco, Pará, e outros portos do Brasil, dos barcos, lanchas e pequenas embarcações que navegavam pelos rios e ribeiras dessa capitania, conduzindo viveiros e pescados para sua manutenção, com o número de marinheiros, pescadores forros e cativos que haviam na capitania, e freguesias onde moravam, 27/05/1775, Cx. 47, D. 8790 e 8812. 
mesmo ano de $1775 .{ }^{25}$ Ainda segundo o mapa sobre a navegação, a capitania contava com 678 marinheiros pretos forros, dos quais 274 moravam na Conceição e 247 no Pilar, e 1.227 marinheiros cativos, sendo que apenas 225 e 101 residiam nestas freguesias, respectivamente. A maioria dos escravos ocupados na marinhagem, cerca de 733, vivia nos subúrbios da cidade e nas vilas do Recôncavo e, de acordo com o mapa, eram "inábeis para a navegação de barra afora, e servem por necessidade as embarcações miúdas", transportando mercadorias e pessoas entre Salvador e sua hinterland. ${ }^{26}$ Tamanha era a falta de mão de obra para a navegação de longo curso "que os navios e corvetas que trilham o comércio de África costumam equipar-se com uma pequena equipagem de quatro ou seis marinheiros brancos, suprindo [com] os pretos cativos para o resto da mareação que carecem". 27

Esta situação fica ainda mais evidente em outro mapa, datado de 30 de junho de 1775 , um mês após esse primeiro. O documento informa sobre os portos onde se encontravam as embarcações baianas, bem como sobre "a gente marítima" que se encontrava embarcada naquele momento, com a totalidade de oficiais e marinheiros brancos, pretos forros e cativos. De acordo com o mapa, "a exceção dos navios que navegam para a Corte e Cidade do Porto", os demais tinham a sua tripulação composta por "muitos pretos cativos, pela grande falta que há de marinheiros brancos". ${ }^{28} \mathrm{O}$ documento enumera 88 embarcações baianas, destas 24

\footnotetext{
${ }^{25}$ AHU, CU, 005-01 Bahia - Coleção Eduardo Castro e Almeida, Mapa das freguesias do Arcebispado da Bahia, com o número de habitantes sujeitos ao governo da capitania, comarcas e vilas a que pertenciam, número de "fogos e almas" para que se soubesse o número de pessoas que poderiam ser tiradas para o serviço de Sua Majestade, sem opressão dos povos, 09/01/1775, Cx 47, D. 8750.

${ }^{26}$ De acordo com o mapa, os 733 marinheiros cativos estavam distribuídos assim nos subúrbios e vilas do Recôncavo: 118 nas freguesias dos subúrbios da Cidade da Bahia, 142 na vila de São Francisco, 58 em Santo Amaro, 157 em Cachoeira, 69 Maragogipe, 189 Jaguaripe.

${ }^{27}$ AHU, CU, 005-01 Bahia - Coleção Eduardo Castro e Almeida, Mapa dos tipos de embarcações que havia na capitania da Bahia, e que navegavam para a Costa da Mina, Angola, e outros portos da África, Rio de Janeiro, Pernambuco, Pará, e outros portos do Brasil, dos barcos, lanchas e pequenas embarcações que navegavam pelos rios e ribeiras dessa capitania, conduzindo viveiros e pescados para sua manutenção, com o número de marinheiros, pescadores forros e cativos que haviam na capitania, e freguesias onde moravam, 27/05/1775, Cx. 47, D. 8790 e 8812.

${ }^{28}$ AHU, CU, 005-01 Bahia - Coleção Eduardo Castro e Almeida, Mapa dos portos onde estavam os navios, corvetas, galeras e sumacas, que navegavam da Bahia para os portos da Europa, África e América, com o número dos oficiais empregados na mareação, equipagem de marinheiros, distinguindo se eram brancos, pretos forros e cativos, 30/06/1775, Cx. 47, D. 8815.
} 
referem-se a corvetas e sumacas que faziam comércio de escravos nos portos de Luanda, Benguela, Moçambique e Costa da Mina, conforme o quadro 3 extraído abaixo.

Ainda de acordo com o mapa, no ano de 1775, havia 1096 indivíduos, entre oficiais e marinheiros, matriculados como tripulantes das 88 embarcações baianas de longo curso ou de cabotagem, que incluíam navios, corvetas, sumacas e galeras, com destino a Lisboa, Porto, Rio de Janeiro, Pernambuco, Rio Real e Cotinguiba, em Sergipe, bem como Alagoas, além de portos africanos

\section{QUADRO 1}

PERFIL DA TRIPULAÇÃO DOS NAVIOS NEGREIROS EM 1775

\begin{tabular}{l|llllll}
\hline & Embarcações & Oficiais & $\begin{array}{l}\text { Marinheiros } \\
\text { brancos }\end{array}$ & $\begin{array}{l}\text { Marinheiros } \\
\text { forros }\end{array}$ & $\begin{array}{l}\text { Marinheiros } \\
\text { cativos }\end{array}$ & $\begin{array}{l}\text { Total } \\
\text { tripulantes }\end{array}$ \\
$\begin{array}{l}\text { Luanda } \\
\text { Benguela }\end{array}$ & 8 & 22 & 40 & 9 & 32 & 103 \\
$\begin{array}{l}\text { Costa } \\
\text { Mina }\end{array}$ & 5 & 19 & 20 & 1 & 38 & 78 \\
Moçambique & 10 & 49 & 31 & 12 & 171 & 263 \\
Totais & 1 & 5 & 10 & 2 & 8 & 25 \\
\hline
\end{tabular}

Fonte: AHU, CU, 005-01 Bahia Coleção Eduardo Castro e Almeida, Mapa dos portos onde estavam os navios, corvetas, galeras e sumacas, que navegavam da Bahia para os portos da Europa, África e América, com o número dos oficiais empregados na mareação, equipagem de marinheiros, distinguindo se eram brancos, pretos forros e cativos, 30/06/1775, Cx. 47, D. 8815.

Diferentemente do mapa produzido em maio, neste último é informada a quantidade de marinheiros brancos, além de apresentar um número menor de libertos engajados na marinhagem. Entre os 422 marítimos brancos, 214 embarcaram em navios com destino a Lisboa que, por sua vez, trazia apenas cinco cativos como tripulantes. As embarcações que se dirigiram para Luanda possuíam a maior quantidade de marujos brancos, 40 ao total, enquanto aquelas que seguiam para os portos da Costa da Mina detinham o maior número de escravos, 171. Lisboa concentrava a maior parte da marinhagem branca, provavelmente, por ser o reino a residência ou a referência de moradia para a maioria desses indivíduos. Ademais, a navegação para a costa africana era assaz perigosa, em virtude do alto índice de mortalidade a bordo e durante a estadia na África, sem contar o risco de sublevação escrava 
durante a viagem. Por isso, a maior parte da gente marítima do tráfico era também africana e escravizada. ${ }^{29}$

O número um pouco mais elevado de brancos na tripulação dos navios que seguiam para Luanda, em comparação com outros portos africanos, talvez se explique por esta ser a principal possessão portuguesa na África. Ou seja, é possível que Angola fosse a residência de parte desses marujos ou que naquela praça eles possuíssem fortes interesses comerciais. Todavia, o que chama atenção acerca da gente marítima que seguia para Luanda, de acordo com o mapa de junho de 1775, é a média de apenas 12,8 tripulantes por embarcação, incluindo aí os oficiais. Este percentual é inferior àquele apresentado pelos navios que seguiam para Benguela, que alcançavam 15,6 e muito abaixo daqueles que se dirigiam para os portos da Costa da Mina, que chegavam a marca de 26,3 tripulantes por navio.

De acordo com Rodrigues, no período oitocentista, os navios negreiros levavam uma média de 20 a 25 tripulantes, superior a outras carreiras, devido a alta taxa de mortalidade durante a viagem e a necessidade de maior número de pessoas, principalmente para controlar a população escrava transportada a bordo.$^{30}$ É possível supor que os dados sobre a equipagem das embarcações que navegavam para Luanda e Benguela estivessem subestimados ou, quiçá, haveria uma incorporação de novos marinheiros a bordo quando da chegada a estas possessões portuguesas. Os senhorios e capitães dos navios, seguindo essa hipótese, devido ao escasso o número de marinheiros disponíveis na capitania da Bahia, cogitariam ser mais vantajoso agregar novos tripulantes nas praças angolanas. Isto seria muito mais difícil de ser feito na Costa da Mina, onde os portugueses não dispunham de um território sob seu controle, contavam com a concorrência de outras nações europeias e a forte presença de reis e potentados africanos nos assuntos do tráfico. Os capitães negreiros, quando necessitavam de mão de obra local na Costa da Mina, geralmente se restringiam à contratação de barqueiros nas proximidades do Castelo de São Jorge ou no litoral da Costa do Ouro, para efetuarem a descarga das mercadorias e auxiliarem no embarque dos cativos. ${ }^{31}$

\footnotetext{
${ }^{29}$ Luiz Geraldo Silva, A faina, a festa e o rito, pp.155-198 e Jaime Rodrigues, De Costa da Costa, pp. 159184. Jaime Rodrigues, No mar e em terra: história e cultura de trabalhadores escravos e livres (São Paulo: Alameda, 2016), pp. 106-131.

${ }^{30}$ Jaime Rodrigues, De Costa a Costa, pp. 167-170.

${ }^{31}$ A corveta $N^{a} S^{a}$ da Esperança e São José quando foi capturada pelos holandeses, em 1767, por exemplo, estava em Cabo Lahu contratando barqueiros africanos para auxiliar na descarga do navio e transporte dos
} 
Outra questão intrigante no mapa de junho de 1775 é o número diminuto de libertos, apenas 51 para todas as 88 embarcações, sendo que somente 24 estavam engajados no tráfico negreiro. Se compararmos estes números com os presentes no documento de maio desse mesmo ano é visível a desproporção. No mapa de maio, os marinheiros forros somavam, somente em Salvador, 543 indivíduos, embora estivessem listados ali todos os envolvidos tanto na navegação de barra fora quanto interna. Porém, a despeito disto, o mapa de junho sugere que apenas 4,5\% dos marinheiros libertos estariam envolvidos na navegação para costa africana em 1775. Esta proporção é totalmente inversa no caso dos marinheiros escravos. No mapa de maio, Salvador, com suas oito freguesias, concentrava 412 dos 1.227 marítimos cativos da capitania e, segundo o documento feito em junho de 1775, 392 estariam em embarcações de barra fora, sendo 249 somente em navios negreiros. Ou seja, a partir destes mapas, pode-se especular que aproximadamente $60 \%$ dos marujos escravos que viviam na Cidade da Bahia labutavam em embarcações negreiras, enquanto os marinheiros forros compunham uma minoria desta tripulação, preferindo engajarem-se na navegação interna.

Cotejando-se os dados dos mapas de maio e junho de 1775 com as informações dos inventários post-mortem, pode-se afirmar que os trabalhadores dos navios negreiros do principal porto da América portuguesa setecentista eram majoritariamente escravos africanos, destes, a maioria era oriunda da Costa da Mina. É certo também que entre os marinheiros escravos da capitania da Bahia, aproximadamente $68 \%$ eram responsáveis pela navegação interna nos rios e baías. Ao lado deles, havia significativo número de libertos, subindo e descendo rios e dominando o transporte de pessoas e mercadorias na Baía de Todos-os-Santos. Tanto escravos quanto forros, ao labutarem em embarcações de pequeno e médio porte, como saveiros e lanchas, conviviam, salvo raras exceções, com a direção de mestres e arrais brancos, numa hierarquia racial que refletia nas águas as diferenças e os conflitos da escravidão em terra.

cativos para bordo. Cf. AHU, CU, Coleção Castro e Almeida, Requerimento do negociante José de Souza Reis à rainha, solicitando para ser indenizado por prejuízos sofridos com a perda da sua corveta Nossa Senhora da Esperança e São José, que os holandeses tinham apresado, em 1767, quando tinha sido fretada pelo governador da Bahia, conde de Azambuja, para conduzir à Ilha do Príncipe, o governador e capitão general de São Tomé e Príncipe, Lourenço Lobo de Almeida, próximo a Costa da Mina, onde tinham sido largados o capitão António da Costa Bastos e a tripulação. 1777, Cx. 51, D. 9619-9631. 
O mesmo se dava nas embarcações de longo curso, especialmente nos navios negreiros. Nestes havia um pequeno número de marujos brancos, incapaz de dar conta de toda a faina, que se somavam aos oficiais da mesma cor. É compreensível que o mapa de junho de 1775 apenas detalhe a cor dos marinheiros, onde havia heterogeneidade. Entre os oficiais não se menciona a cor, certamente porque para o escrivão e para o leitor a quem se dirigia aquele documento seria redundante informar o óbvio. No império marítimo português, um posto de comando e poder, como o de capitão, mestre ou piloto de navios de longo curso, naturalmente seria exercido por brancos. Em contrapartida, a marinhagem das tripulações negreiras era formada por expressivo contingente de escravos, em sua maioria de origem africana, junto com alguns libertos, identificados, geralmente, apenas como pretos forros. O trabalho desses africanos escravos e libertos, no entanto, começava muito antes da embarcação flutuar.

\section{A carreira do tráfico negreiro na Costa da Mina}

Embora a maioria das embarcações construídas na Ribeira das Naus tivesse por finalidade o comércio com o reino e o Oriente, o estaleiro chegou a fabricar navios voltados para o tráfico negreiro. ${ }^{32} \mathrm{O}$ iate Santo Andre e Santa Ana, por exemplo, foi fabricado por ordem régia e financiado por Mathias de Torres Bezerra, com o objetivo de transportar missionários para São Tomé e traficar escravos para o Brasil. Segundo o governador daquela ilha, as embarcações que comumente se dirigiam a Costa da Mina não possuíam cômodos próprios para os eclesiásticos. Os custos de tal empreitada seriam cobertos com a cobrança de fretes para o transporte de escravos da Costa da Mina para a Bahia e Rio de Janeiro. O financiador da iniciativa de proporcionar maior conforto ao clero que se dirigia a São Tomé, Mathias de Torres Bezerra, era um importante negociante que atuava há longas datas no tráfico entre a Bahia e a Costa da Mina. De acordo com os dados do TSTD, era dono de pelo

\footnotetext{
${ }^{32}$ A Ribeira das Naus funcionava como estaleiro real foi criada no século XVI na freguesia da Conceição da Praia, próximo ao prédio da alfândega, com o objetivo de oferecer manutenção aos navios oriundos do Oriente e construir embarcações de grande porte voltadas para este comércio. De acordo com Amaral Lapa e Francisco Borges de Barros, no regimento trazido pelo governador-geral Tomé de Souza, fundador da cidade de Salvador em 1549, constava a criação da Ribeira das Naus. Ver: Amaral Lapa, A Bahia e a carreira da Índia, pp. 60-65 e 81. Francisco Borges de Barros, Novos documentos para a História Colonial, (Salvador: Imprensa Oficial da Bahia, 1931), pp. 18-19.
} 
menos três embarcações responsáveis por, no mínimo, cinco viagens à Costa da Mina entre os anos de 1739 e $1742 .^{33}$

Em outra ocasião, por volta de 1775, o negociante e capitão Teodósio Gonçalves Silva, requereu autorização régia para construir um navio mercante na Ribeira das Naus de 160 palmos de quilha. Segundo o capitão, o estaleiro da Preguiça e o de Itapagipe, distante a uma légua da cidade, não tinham capacidade de fabricar embarcação de tal tamanho, por lhe faltar profundidade. Sobre a matéria, o governador da capitania, Manuel da Cunha Menezes, afirmou ser o requerente experimentado armador da carreira do tráfico negreiro, pois já havia mandado construir dois navios nos estaleiros da cidade. É possível que um deles fosse a corveta $N^{a} S^{a}$ das Brotas e São João Nepomucebo e Almas, que o próprio Teodósio Gonçalves Silva havia capitaneado no ano anterior, em sua viagem à Costa da Mina. ${ }^{34}$ No entanto, o intendente da marinha, Rodrigo da Costa Almeida, contrapôs o suplicante, argumentando ser o estaleiro de Itapagipe o melhor para construção daquele tipo de embarcação. Ademais, em seu despacho, destacou que o capítulo 21 do regimento real da Ribeira estabelecia que "dentro dela se não trabalhe em outra obra que não seja sua pelos inconvenientes que podem haver". 35

Em 1776, um ano após Teodósio Gonçalves Silva ter recebido o indeferimento do seu requerimento, os homens de negócio da praça da Bahia propuseram ao marquês de Pombal a construção de um estaleiro de pedra na cidade. Segundo o projeto, o equipamento se

\footnotetext{
${ }^{33}$ TSTD, viagens: \#50620, \#50621, \#50637, \#51951, \#52007. Os navios pertencentes a Bezerra eram: a Sumaca $N^{a} S^{a}$ das Mercês Santo Antônio e Almas e as galeras $N^{a} S^{a}$ da Conceição e Graça e $N^{a} S^{a}$ da Conceição da Praia Santo Antônio e Almas.

${ }^{34}$ TSTD \#50986. Além desta embarcação, de acordo com este banco de dados, Teodósio Gonçalves Silva era proprietário de, pelo menos, mais quatro e cada uma teria realizado uma viagem entre os anos de 1757 e 1796. Cf. TSTD \#40465, \#40474, \#50773, \#50802. O negociante também era senhorio do navio Santíssimo Sacramento e $N^{a} S^{a}$ do Pilar, vendido, em 1777, para Fazenda Real por ordem do governador-geral Manuel da Cunha Menezes, sendo em seguida equipado e armado para guarnecer o Rio de Janeiro. Cf. Marieta Alves, "O comércio marítimo e alguns armadores do século XVIII, na Bahia", Revista de História, vol. XXXI, nº 63, p. 137.

${ }^{35}$ AHU, CU, 005-01 Bahia - Coleção Eduardo Castro e Almeida, Ofício do governador Manuel da Cunha Menezes ao [secretário de Estado da Marinha e Ultramar] Martinho de Melo e Castro, sobre o desenvolvimento da construção dos navios mercantes, e um requerimento de Teodósio Gonçalves Silva, 03/10/1775, Cx. 48, D. 8951-8956. Documento também citado por Amaral Lapa, A Bahia e a carreira da Índia, p. 62 e por Marieta Alves, "O comércio marítimo e alguns armadores do século XVIII na Bahia", Revista de História da USP, 1965, pág. 136. Para saber mais informações sobre o mestre de campo Teodósio Gonçalves da Silva ver: Cristiana Ferreira Lyrio Ximenes, "Bahia e Angola: redes comerciais e o tráfico de escravos 1750-1808", (Tese de Doutorado, Departamento de História, Universidade Federal Fluminense, 2012), pp. 247-248.
} 
estenderia do forte da Ribeira das Naus até as pedras da Barra, porém o ofício não obteve resposta do ministro de d. José. Entre os nomes que ensejaram a proposta constam oito senhorios de navios negreiros e cinco negociantes que comercializavam em direção ao reino. $^{36}$

A despeito da omissão régia com relação a esta questão, é salutar como a ampliação da construção naval na capitania não escapava aos interesses e ao dinamismo do tráfico negreiro. Este comércio, juntamente com a exportação de açúcar e tabaco e a importação de produtos europeus, dinamizavam a economia da Cidade da Bahia, que se voltava para atender a demanda de mão de obra marítima e portuária. Os negócios com a Costa da Mina, por sua vez, exigiam mercadorias específicas, como o fumo, mas também grandes quantidades de farinha de mandioca e outros alimentos. Os navios da carreira negreira eram construídos nos estaleiros de Salvador, quando do contrário, sofriam às adaptações necessárias nesse espaço e, seguindo a lógica escravista da cidade, tinham à frente das principais atividades de manutenção, construção e abastecimento, trabalhadores escravizados.

Em fins do século XVIII, numa conjuntura em que o tráfico baiano de escravos ganhou novo fôlego após a revolução na colônia francesa de Saint Domingues, a construção de navios negreiros obteve grande impulso. A ponto do governador geral, d. Fernando José de Portugal, conceder um generoso subsídio a d. Ana Joaquina de São Miguel Cardoso, viúva de Antônio Cardoso dos Santos, tenente coronel, tesoureiro-geral e grande traficante de escravos. ${ }^{37}$ A viúva tocava muito bem os negócios do seu falecido marido. Durante mais de

\footnotetext{
${ }^{36}$ AHU, CU, 005-01 Bahia - Coleção Eduardo Castro e Almeida, Ofício do governador Manuel da Cunha Menezes ao marquês de Pombal, recomendando a iniciativa dos comerciantes da Bahia para a construção de um estaleiro de pedra. Representação de comerciantes da Bahia solicitando licença para construírem um estaleiro de pedra, desde a cortina do Forte da Ribeira até as pedras que estavam de parte da Barra, 18/04/1776, Cx. 49, D. 9122-9124. Os proprietários de navios negreiros que assinaram o documento foram: Antônio Cardoso dos Santos, Clemente José da Costa, Luis Coelho Ferreira, Manoel de Oliveira, David Oliveira Lopes, Fructuoso Vicente Viana, Teodósio Gonçalves da Silva, Manoel Pereira de Andrade, seguidos pelos negociantes: Francisco Borges dos Santos, Manoel Gonçalves Chaves, Antônio Gonçalves Viana, Antônio Lopes Menezes, Manuel Álvares Monteiro. Este documento também foi citado por José Roberto do Amaral Lapa, A Bahia e a carreira da Índia (Ed. Fac-similar, São Paulo, Hucitec, Unicamp, 2000), pp. 61-62. Sobre o perfil dos principais comerciantes da praça da Bahia cf. Cristiana Ferreira Lyrio Ximenes, "Bahia e Angola: redes comerciais e o tráfico de escravos 1750-1808" (Tese de Doutorado, Universidade Federal Fluminense, 2012), pp. 245-263.

${ }^{37}$ Comerciante de grosso trato e proprietário de várias embarcações negreiras, o tenente coronel Antônio Cardoso dos Santos foi nomeado tesoureiro geral e deputado da Junta de Administração da Real Fazenda, cargo
} 
dez anos, desde que enviuvara, em 1787, até 1798, havia sido responsável pela armação de, pelo menos, treze viagens em direção à Costa da Mina, que desembarcaram, aproximadamente, 4.106 africanos para o Brasil. ${ }^{38}$ Duas destas viagens foram realizadas em sociedade com outras mulheres, algo bastante raro no mundo do tráfico. Ao lado de d. Ana Quitéria do Nascimento, d. Ana Cardoso enviou para a Costa da Mina o navio $N^{a} S^{a} d a$ Lampadosa e Santo Antônio Aurora em 1795. Anos antes, em 1788, em conjunto com Maria Luciana da Trindade havia encaminhado para o mesmo destino a corveta São João Santo Antônio e Almas. Trindade era uma dona com larga experiência no tráfico, encabeçava armações negreiras desde 1780 e foi parceira comercial do falecido marido de Ana Joaquina Cardoso. ${ }^{39}$ Com o comércio negreiro em expansão, o governador-geral d. Fernando José de Portugal, por meio de ofício em 25 de setembro de 1796, isentou a viúva de pagar direitos alfandegários sobre os materiais requeridos para construção de uma embarcação. $\mathrm{O}$ documento não especificava se o navio em questão estava sendo fabricado na Ribeira das Naus ou em um estaleiro particular. ${ }^{40}$

A despeito disto, até esta embarcação zarpar em direção a costa africana havia muito trabalho a ser feito. Além da construção e manutenção das embarcações, carga e descarga das mercadorias, a faina em terra para assegurar a partida dos navios negreiros incluía intenso trabalho nos armazéns e trapiches existentes nas freguesias da Conceição e do Pilar. O tabaco exportado para a Costa da Mina, ao chegar do Recôncavo, ficava armazenado nos trapiches. Antes de embarcar, passava pela Alfândega, onde era pesado e se efetuava a arrecadação da dízima. O transporte do Recôncavo até os trapiches de Salvador e deles para

que ocupou até o seu falecimento em 1786, Cristiana Ferreira Lyrio Ximenes, "Bahia e Angola”, p. 246. Jaime Rodrigues, De Costa a Costa, p. 137.

38 TSTD viagens: \#40790; \#47726; \#51155; \#51156; \#51170; \#51174; \#51182; \#51200; \#51213; \#51217; \#51229; \#51273; \#52078.

${ }^{39}$ Cristiana Ferreira Lyrio Ximenes, "Bahia e Angola", pp.161 e 168. TSTD viagens: \#51213 e \#51156.

${ }^{40}$ AHU, CU, 005-01 Bahia - Coleção Eduardo Castro e Almeida, Ofício do governador D. Fernando José de Portugal ao [ministro e secretário de Estado dos Negócios Estrangeiros e da Guerra] Luiz Pinto de Souza Coutinho informando que tinha dado ordens para que os materias do fabrico de uma nau que estava sendo construída no Estaleiro da Ribeira por conta de dona Ana Joaquina de São Miguel Cardoso fossem despachados sem direito, 25/09/1796, Cx. 86, D. 16718. De acordo com o TSTD, Ana Joaquina de São Miguel Cardoso era proprietária das embarcações: $N^{a} S^{a}$ Mãe dos Homens Vitória e Almas, São João Santo Antônio e Almas, estas duas herdadas do seu falecido marido e a $N^{a} S^{a}$ da Lampadosa e Santo Antônio Aurora,São João Nepomuceno e São Francisco de Paula, estas últimas, provavelmente, adquiridas e/ou construídas depois do falecimento de Antônio Cardoso dos Santos. As viagens feitas nestes navios registradas pelo TSTD foram: \#40790, \#47726, \#51155, \#51156, \#51170, \#51174, \#51182, \#51200, \#51213, \#51217, \#51229, \#51273, \#52078. 
alfândega cabia aos escravos, bem como a pesagem que exigia "laborarem com o violento peso das balanças".

Nessa última etapa, que incluía todas as mercadorias que seguiam para costa africana, ou seja, rolos de fumo, caixas de açúcar, pipas de aguardente, baiões de doces e fazendas, o transporte ficava a cargo dos cativos pertencentes aos donos dos trapiches. Segundo eles, tratava-se de "laborioso e incansável serviço [feito] com assistência dos caixeiros [e sobre o qual] podem testemunhar os comerciantes que habitam nas vizinhanças dos trapiches". Para carregar o navio, contava-se ainda com a diligência dos marinheiros, em sua maioria "escravos [que] repartidos em pelotões tornam a arrumar com suma presteza, e dobradas forças. Este incansável, e rigoroso trabalho, continuado não só de dia em dia, senão de noite e noite". ${ }^{41}$

Acrescente-se ainda, o embarque dos mantimentos para a viagem, que incluíam arroz, feijão, milho, azeite, vinagre, peixe seco, carne salgada e, principalmente, farinha de mandioca. Em geral, os navios buscavam transportar a quantidade de farinha necessária para alimentar a tripulação e os cativos traficados durante todo o giro da viagem. A maioria preferia adotar esta medida, em vez de aventurar adquirir suprimentos nas ilhas de São Tomé e Príncipe, embora às vezes fosse preciso complementar o estoque. A demanda dos navios negreiros por farinha era tamanha que ocasionava inflação e desabastecimento do produto na cidade Salvador. A Câmara tentou adotar diversas medidas para obrigar os senhorios de embarcações a cultivarem roças de mandioca, em alguns casos apelaram a autoridade régia, mas os traficantes mantiveram-se recalcitrantes a estas ações. ${ }^{42}$

\footnotetext{
${ }^{41}$ ANTT, Junta do Comércio, Petição dos donos de trapiches da Cidade da Bahia à Mesa de Inspeção, 15/12/1786, Caixa 38, Maço 10, D. No 3.

${ }^{42}$ Repertório de fontes sobre a escravidão existentes no Arquivo Municipal de Salvador. As Posturas (1631/1889). Postura Municipal de 3/12/1696, Postura Municipal de 12/02/1710, Postura Municipal de 1716 (Salvador: Fundação Gregório de Matos, Prefeitura Municipal de Salvador, 1988), p. 19, 23, 27, 34. Em 1730, as posturas emitidas pela Câmara foram ratificadas através de uma Ordem Régia, Cf.: APEB, Seção Colonial/Provincial, Ordens Régias, Carta do vice-rei ao rei de Portugal em resposta dando parecer favorável à conservação da lei que se obriga plantar roças para provimento da farinha as embarcações, 31 de agosto de 1730, vol 27, doc 112-a. AHU, ACL, CU, 005 Coleção Bahia Avulsos, Consulta do Conselho Ultramarino ao rei D. João V sobre a representação do provedor e mais deputados da mesa do comércio da cidade da Bahia, em que pedem ordem para que o senado da Câmara não obrigue os homens de negócio e proprietário de embarcações a plantar farinha. Anexo: 4 documentos. 21/05/1732, Cx. 42, D. 3767.
} 
Concluído o carregamento da embarcação, cujas mercadorias pertenciam a diversos investidores, numa complexa sociedade mercantil em que o senhorio era apenas o investidor principal, finalizavam-se os despachos na Alfândega e na Mesa de Inspeção. Autorizado a partir, levantava-se a âncora. Durante a viagem de ida, o trabalho dos marujos se detinha mais ao convés. Consistia, principalmente, no manejo das velas e cabos do massame, além da limpeza do navio, como em qualquer navegação de longo curso. Os marinheiros escravos, que pertenciam a oficias da embarcação, davam conta ainda de prestar serviços pessoais aos seus amos.

Quando o navio se aproximava da costa africana, o trabalho adquiria particularidades concernentes ao tráfico negreiro. Cabia aos marinheiros arrumarem as mercadorias a bordo, de modo a facilitar e agilizar o desembarque. Segundo o engenheiro régio José Antônio Caldas, os capitães costumavam contratar canoeiros na Costa do Ouro ou nas proximidades do castelo de São Jorge da Mina para assistirem na descarga e transporte dos escravos até o navio. ${ }^{43}$ Após ancorar a embarcação no porto escolhido, o capitão e o contramestre, auxiliados por marinheiros, alguns inclusive africanos que atuavam como intérpretes, se dirigiam a terra para iniciar a comercialização. As negociações poderiam durar meses e percorrer diversos portos na Costa da Mina, até que a embarcação completasse a sua carga, ou seja, comercializasse toda a mercadoria trazida a bordo e abarrotasse o navio com o maior número possível de escravos. ${ }^{44}$

A partir de então, os marinheiros, em sua maioria cativos como já foi dito, assumiam também a função de carcereiros. Conforme salientado por Mary Hicks, a especialidade marítima desses homens incluía a capacidade de administrar os escravos que seguiam no porão do navio. Entre eles, o cozinheiro possuía papel fundamental, pois era responsável por controlar as provisões, devendo estar afinado com as expectativas do capitão e do contramestre com relação à duração da viagem. Além da vigilância, da distribuição de

\footnotetext{
${ }^{43}$ José Antônio Caldas, Notícia Geral de toda essa Capitania da Bahia, desde o seu descobrimento até o presente ano de 1759, Edição fac-similar, (Salvador: Tipografia Beneditina, 1951), pp. 287-315.

${ }^{44}$ Marcus Rediker, A hidra de muitas cabeças: marinheiros, escravos, plebeus e a história oculta do Atlântico revolucionário (São Paulo: Companhia das Letras, 2008), pp. 240-247. Jaime Rodrigues, De costa a costa: escravos, marinheiros e intermediários do tráfico negreiro de Angola para o Rio de Janeiro (1780-1860) (São Paulo: Companhia das Letras, 2005), pp.159-184. Mary Ellen Hicks, "The Sea and the Shackle: African and Creole Mariners and the Making of a Luso-African Atlantic Commercial Culture, 1721-1835" (Tese de Doutorado, University of Virginia, 2015), pp. 115-116;125; 141-153.
} 
comida e água, os marinheiros eram responsáveis por trazer as turmas de escravos do porão para o convés, a fim de respirarem ar fresco, tomarem sol e praticarem exercício. Em geral, estimulava-se que eles dançassem, para isso tocava-se instrumentos percussivos e não se abria mão do uso do chicote contra aqueles mais recalcitrantes em se movimentarem. Esta atividade requeria estrito zelo para evitar que os cativos cometessem suicídio, lançando-se ao mar. Ademais, cabia aos marinheiros, e suponho que esta tarefa recaísse mais sobre aqueles que eram escravos, a limpeza do porão, onde os seres humanos eram empilhados como mercadoria. Segundo Oliveira Mendes, duas vezes por semana, os capitães mandavam os marinheiros lavarem a coberta e, com o auxílio de esponjas, lançar vinagre com o objetivo de tentar remediar, inutilmente, o cheiro fétido que reverberava a morte, principal companheira do navio, e que lhe garantia a alcunha de tumbeiro. ${ }^{45}$

A mortalidade dos navios negreiros não distinguia cor nem status social e ceifava a vida de capitães, oficias, marujos e escravos, embora vitimasse muito mais aqueles que viajam no porão, devido as condições insalubres, sendo um dos principais fatores de insucesso de uma viagem negreira. Se a morte dos cativos encarcerados no porão poderia significar prejuízos, o passamento da maioria da tripulação também poderia deixar seus sobreviventes em risco, sobretudo de sublevação. Apesar do perigo de morte e do trabalho fatigante, a vida marítima nas embarcações negreiras, como já foi dito, atraía alguns libertos.

A corveta $N^{a} S^{a}$ da Esperança e São José, pertencente a José de Souza Reis, por exemplo, contava com alguns forros em sua tripulação. João Álvares Chaves da Piedade era um deles, "homem preto forro, casado e oficial de tanoeiro", residia na rua Nova de São Bento, freguesia de São Pedro Velho. À época do seu depoimento acerca da apreensão da corveta, afirmou ter 35 anos. Contou ainda que após a abordagem holandesa em Cabo Lahu, a embarcação foi levada para o castelo de São Jorge da Mina, onde a tripulação fora obrigada a desembarcar. Neste momento, ficou bem registrado em sua memória como as pessoas de sua origem eram tratadas como inferiores, independente da sua condição jurídica. Piedade

\footnotetext{
${ }^{45}$ João José Reis, Flávio dos Santos Gomes e Marcus J M de Carvalho, O Alufá Rufino: tráfico, escravidão e liberdade no Atlântico negro (c.1822-c.1853) (São Paulo: Companhia das Letras, 2010), pp. 99-115. Luís Antônio de Oliveira Mendes, Memória a respeito dos escravos e tráfico da escravatura entre a Costa d'África e o Brasil [1793] (Salvador: P555, 2013), pp. 50-51. Marcus Rediker, O navio negreiro: uma história humana (São Paulo: Companhia das Letras, 2011), pp. 237-242.
} 
relatou que "os pretos da corveta foram presos com ferros nos pés", inclusive ele, enquanto "os brancos foram mantidos com sentinelas a vista" e assim permaneceram durante 30 dias. $^{46}$

Manoel de Freitas foi outro marinheiro a bordo da corveta $N^{a} S^{a}$ da Esperança e São José. Em seu depoimento disse "ser forro e marítimo, morador ao Corpo da Guarda da Praia", ou seja, na freguesia da Conceição, com "idade que representa ter 40 anos". Freitas confirmou o relato de Piedade, afirmando que, ao chegarem ao Castelo de são Jorge da Mina, os pretos marinheiros forros e cativos foram postos "em grilhões por espaço de um mês, tratando a todos mal". Acrescentou também que findado esse tempo, a tripulação foi solta e cada marinheiro recebeu para seu transporte "ainda menos do valor de vinte patacas" [6\$400], sem que lhe fosse possível "tirar coisa alguma do que era seu" de dentro da corveta, "nem ainda o próprio vestuário de cada um". Por "coisa alguma do que era seu”, certamente, Manoel de Freitas se referia a pequenas cargas que marinheiros libertos e livres comumente transportavam para comercializarem produtos na Costa da Mina, como panos da Costa, peças de marfim e, até mesmo, escravos.

Mas por que libertos abraçavam uma atividade deveras perigosa, de trabalho árduo, em que a morte estava sempre a espreitar? As péssimas condições e o iminente risco de morte explicam porque grande parte da marinhagem a bordo dos tumbeiros era composta por escravos, que recebiam soldadas consubstanciais. Cabe ressaltar que as possibilidades de sobrevivência dos libertos na sociedade colonial eram limitadas. Em regra, após alcançarem a emancipação, exerciam atividades semelhantes àquelas do tempo do cativeiro. Ademais, muitos alcançavam a liberdade descapitalizados pelo pagamento de onerosa alforria. Logo, um salário atrativo, associado às possibilidades de negócio que uma viagem à costa africana poderia proporcionar eram fatores a serem considerados por muitos libertos.

\footnotetext{
${ }^{46}$ AHU, CU, 005-01 Coleção Eduardo Castro e Almeida, Requerimento do negociante José de Souza Reis à rainha, solicitando para ser indenizado por prejuízos sofridos com a perda da sua corveta Nossa Senhora da Esperança e São José, que os holandeses tinham apresado, em 1767, quando tinha sido fretada pelo governador da Bahia, conde de Azambuja, para conduzir à Ilha do Príncipe, o governador e capitão general de São Tomé e Príncipe, Lourenço Lobo de Almeida, próximo a Costa da Mina, onde tinham sido largados o capitão António da Costa Bastos e a tripulação, 1777, Cx. 51, D. 9619-9631. O depoimento do liberto Manoel de Freitas foi encontrado neste mesmo documento, sobre o qual faço menção para não precisar repetir a referência.
} 
Estes cotidianamente enfrentavam uma sociedade preconceituosa, que estigmatizava a origem africana, tornando a sobrevivência um enorme desafio. ${ }^{47}$

A vida marítima, portanto, apesar de arriscada, poderia significar uma alternativa para esses homens. As soldadas pagas às tripulações negreiras costumavam serem maiores que aquelas praticadas pela marinha mercante. Na sumaca $N^{a} S^{a}$ da Assunção Santo António e Almas, por exemplo, estava previsto o pagamento de $700 \$ 000$ réis para o capitão, soma correspondente a venda de sete africanos recém desembarcados na Bahia. Já as soldadas do barbeiro e tanoeiro foram estipuladas em $80 \$ 000$ réis e cada marinheiro, fosse escravo ou liberto, receberia $40 \$ 000$ réis. ${ }^{48}$

As embarcações poderiam levar de seis meses a um ano e meio ou mais para completarem seu giro. Todavia, não apenas o valor da soldada atraía o engajamento de forros na vida marítima. A possibilidade de levarem alguma mercadoria com o objetivo de comercializar produtos na costa africana e revendê-los na Bahia, como pano da costa, peças de marfim e até mesmo escravos, era bastante atrativa. Desta forma, muito marujos transportavam alguns rolos de fumo ou outra mercadoria qualquer do tráfico para adquirirem cativos para si ou como intermediários de terceiros. Realizar a aquisição de um escravo diretamente no continente africano, com menor custo, mesmo descontando o frete e o coartiamento pago aos holandeses, mostrava-se ser um negócio deveras vantajoso. ${ }^{49}$

O marinheiro João da Costa do Nascimento soube muito bem aproveitar essas pequenas oportunidades de negócio abertas pela vida marítima. Crioulo forro, casado com a preta forra jeje Anna Maria da Conceição, segundo seu inventário, aberto em 1802, teria

\footnotetext{
${ }^{47}$ John Russel-Wood, Escravos e Libertos no Brasil Colonial (Rio de Janeiro: Civilização Brasileira, 2005), pp. 105-154. Sílvia Hunold Lara, Fragmentos setecentistas: escravidão, cultura e poder na América Portuguesa (São Paulo: Cia das Letras, 2007), pp.79-172.

${ }^{48}$ Representação acerca de uma sumaca portuguesa apresada pelos ingleses na Costa da Mina, 1782, BNL, Coleção Pombalina, Documento 635 - F. 4728, fl 5-6.

${ }^{49}$ Coartiamento se referia a exigência feita pelos holandeses aos navios luso-brasileiros, obrigando-os a pagarem $10 \%$ da sua carga de fumo em troca de um passaporte que os autorizava a navegar e comercializar nos portos da Costa da Mina, do contrário poderiam ter suas embarcações apreendidas e saqueadas. Esta cobrança perdurou entre o último quartel do século XVII até meados da década de 1790. Cf. Pierre Verger, Fluxo e refluxo do tráfico de escravos entre o golfo do Benin e a Bahia de Todos os Santos: século XVII ao XIX (São Paulo: Corrupio, 1987), passim. Sobre a compra de escravos por libertos embarcados em negreiros diretamente na costa africana no século XIX, ver: João Jose Reis, Marcus Carvalho e Flávio Gomes, $O$ Alufá Rufino: tráfico, escravidão e liberdade no Atlântico negro (c.1822-c.1853) (São Paulo: Companhia das Letras, 2010), passim.
} 
falecido "vindo de volta da Costa da Mina na embarcação do capitão Felix", onde labutava como marinheiro. Morte talvez inesperada, pois não deixou testamento antes de viajar. É possível que a "embarcação do capitão Felix" seja o bergantin Guia, pertencente a Felix da Costa Lisboa e que fora por ele capitaneado, junto com Antônio José S. Boaventura, em direção à Costa da Mina, partindo de Salvador, em dezembro de 1801, retornando em março de 1802, com aproximadamente 353 escravos. ${ }^{50}$

João da Costa do Nascimento não possuía herdeiros ascendentes nem descendentes a não ser sua esposa, com quem casou na Igreja da Sé, em 2 de agosto de 1788. Não havia nascido na Bahia, mas sim na freguesia de $\mathrm{N}^{\mathrm{a}} \mathrm{S}^{\mathrm{a}}$ das Naus da Paraíba do Norte, sendo filho legítimo de Ignacio da Costa e Esperança Pereira, ambos pretos jejes. Não se sabe como veio parar em Salvador, mas nesta cidade encontrou sua companheira, Ana Maria da Conceição preta jeje, que havia sido escrava de Catharina de Araújo Silva. O casamento entre crioulos e africanos nesse período, em Salvador, não era algo assaz comum. Talvez, por ser um crioulo de primeira geração, Nascimento tenha constituído relações junto à comunidade étnica de seus pais e se casado com uma preta forra jeje. ${ }^{51}$

Nos círculos de amizades mais próximas ao casal, no entanto, não deixavam de existir pessoas negras nascidas no Brasil. A viúva, por exemplo, apresentou três crioulos forros que exerciam ofícios ligados ou a construção naval ou a vida marítima como testemunhas da inexistência de herdeiros obrigatórios de seu falecido marido junto ao juiz dos órfãos e ausentes. O primeiro deles foi Fructuozo de Oliveira de 39 anos, solteiro, morador à Quitanda Velha, que vivia do ofício de carpina e sabia assinar seu próprio nome. Custódio de Araújo Silva também era carpinteiro e assinou o seu depoimento, era viúvo, possuía cerca de 46 anos e morava no Beco do Grelo, na mesma casa em que residia o defunto João da Costa Nascimento. Somente Bento Francisco Antônio, de 42 anos, solteiro, morador à rua da Conceição da Praia, vivia do mesmo "ofício de andar embarcado por marinheiro para a Costa da Mina". Os três residiam na freguesia da Conceição e não é de se estranhar que suas

\footnotetext{
50 TSTD \# 51365. APEB, Seção Judiciária, Inventário post-mortem de João da Costa Nascimento, 1802, classificação: 4-1705-2175-5. Para evitar a repetição de notas, informo que os dados apresentados sobre João da Costa Nascimento foram retiradas deste inventário.

${ }^{51}$ Raiza Cristina Canuta da Hora, "Sob os olhos do Bonfim: africanos em suas vivências matrimoniais, familiares e sociabilidades na Cidade da Bahia nos séculos XVIII e XIX (1750-1810)" (Dissertação de Mestrado, Departamento de História, Universidade Federal da Bahia, 2015), pp. 110-151.
} 
relações de cumplicidade envolvessem o fato de serem crioulos forros e integrarem o "povo mecânico" da cidade. ${ }^{52}$

Entre os bens legados por Nascimento havia dois escravos, ambos moços, do gentio da Costa da Mina, avaliados cada um em 100\$000 réis. José do serviço de saveiro, trabalhava provavelmente no transporte de mercadorias entre Salvador e Recôncavo ou no carregamento de embarcações no porto. Ou seja, marinheiro como seu senhor. Porém, atuando na navegação interna, quiçá ganhando experiência em embarcações de pequeno porte para mais adiante aprender os misteres da faina marítima de longo curso. Havia também a escrava Maria do serviço da casa. Além disso, o marido de Ana Maria da Conceição lhe havia deixado oito peças de panos da Costa, cada uma avaliada em $\$ 600$ réis, perfazendo o total de $4 \$ 800$ réis. Bens que certamente o defunto adquiriu com as soldadas e os negócios que a marinhagem para a Costa da Mina poderia lhe permitir. Além disso, demonstrando requinte e distinção, João da Costa do Nascimento possuía um relógio James Pay London $\mathrm{n}^{\mathrm{o}}$ 2095, com duas caixas de cobre douradas, mostrador de esmalte, ponteiro amarelos avaliado em $10 \$ 000$ réis. É lícito imaginar que talvez o tenha adquirido diretamente com os ingleses, na Costa da Mina. O envolvimento no tráfico negreiro constituiu uma oportunidade de sobrevivência e de amealhar algum patrimônio para muitos libertos, como João da Costa Nascimento. Numa sociedade em que a origem e a cor da pele eram determinantes para definir o lugar de um indivíduo, a posse de bens assegurava não apenas alguma estabilidade econômica, mas também certo prestígio social, principalmente se a propriedade em questão fosse escrava.

\section{Conclusão:}

As teias do tráfico negreiro se espelharam por toda Cidade da Bahia e tornaram parte considerável dos seus habitantes dependentes diretos ou indiretos deste comércio. Ao longo dos Setecentos, partiram da Baía de Todos-os-Santos mais de 2.632 viagens, que resultaram no desembarque de aproximadamente 735.528 africanos sobre suas águas, tornando Salvador o principal porto negreiro da América portuguesa no período. ${ }^{53}$ A cidade, em

\footnotetext{
52 Ubiratan Castro de Araújo, "A política dos homens de cor no tempo da Independência” Estudos Avançados, no 18 , vol. 50, 2004, pp. 253-269.

53 TSTD, https://www.slavevoyages.org/voyage/database\#tables, acessado em 05/04/2021.
} 
especial suas freguesias portuárias, se movimentava seguindo a dinâmica das embarcações que cruzavam o Atlântico, mas também daquelas que traziam mercadorias do Recôncavo e de outras capitanias. Por isso, seu ancoradouro não tinha como deixar de ser um polo logístico da navegação de cabotagem, como também de longo curso. Este artigo buscou destacar como africanos e seus descendentes libertos e/ou escravizados foram fundamentais para a infraestrutura e logística do comércio negreiro na Cidade da Bahia ao longo do século XVIII. Deste modo, o trabalho caminhou junto aos estudos que analisam o tráfico negreiro para além das estatísticas, inserindo-o na história social. Contudo, ainda há um amplo campo de trabalho em aberto, sobretudo em relação aos portos de Salvador, Recife e Rio de Janeiro na época colonial, uma vez que a historiografia, predominantemente, tem se voltado para as experiências no Atlântico Norte ou, no caso do Brasil, para o século XIX. A escravidão nas cidades portuárias arrastou consigo africanos e seus descendentes para as lides do mar, onde assumiam as tarefas mais indigestas, árduas e perigosas. As possibilidades de auferir maiores ganhos com soldadas ou com pequenos investimentos no comércio com a África, incluindo a aquisição de cativos, demonstra o quanto formavam a base da pirâmide do trabalho marítimo. Isto porque, esses ativos se assemelhavam mais a migalhas em comparação com as fortunas e a acumulação de capitais nas Américas e na Europa proporcionadas pelo tráfico transatlântico de africanos. ${ }^{54} \mathrm{O}$ comércio negreiro, por fim, se causava terror e sofrimento às suas vítimas, ao longo dos Setecentos, expandiu também o séquito daqueles que consideravam a instituição da escravidão legítima e dela se beneficiavam.

\footnotetext{
${ }^{54}$ Eric Williams, Capitalismo e Escravidão, $1^{\mathrm{a}}$ ed. (São Paulo: Cia das Letras, 2012); Joseph Miller, Way of Death: Merchant Capitalism and Angola Slave Trade, 1739-1830, (Wisconsin: The University Wisconsin Press, 1988); Luiz Filipe de Alencastro, O Trato dos Viventes: formação do Brasil no AtlânticoSul, (São Paulo: Companhia das Letras, 2000).
} 